[Agr. Biol. Chem., Vol. 36, No. 11, p. 1869 1876, 1972]

\title{
Elimination, Replacement and Isomerization Reations by Intact Cells Containing Tyrosine Phenol Lyase ${ }^{\dagger}$
}

\author{
By Hitoshi Ener, Hiroshi Matsui, Shinji Okumura \\ and Hideaki YAMADA* \\ Central Research Laboratories, Ajinomoto Co., Ltd., Kawasaki \\ * Research Institute for Food Science, Kyoto University, Kyoto \\ Received February 8, 1972
}

\begin{abstract}
Tyrosine phenol lyase catalyzes a series of $\alpha, \beta$-elimination, $\beta$-replacement and racemization reactions. These reactions were studied with intact cells of Errinia herbicola ATCC 21434 containing tyrosine phenol lyase.

Various aromatic amino acids were synthesized from L-serine and phenol, pyrocatechol, resorcinol or pyrogallol by the replacement reaction using the intact cells. L(D)-Tyrosine, 3,4dihydroxyphenyl-L(D)-alanine (L(D)-dopa), L(D)-serine, L-cysteine, L-cystine and $S$-methyl-Lcysteine were degraded to pyruvate and ammonia by the elimination reaction. These amino acids could be used as substrate, together with phenol or pyrocatechol, to synthesize L-tyrosine or L-dopa via the replacement reaction by intact cells. L-Serine and D-serine were the best amino acid substrates for the synthesis of L-tyrosine or L-dopa. L-Tyrosine and L-dopa synthesized from D-serine and phenol or pyrocatechol were confirmed to be entirely L-form after isolation and identification of these products. The isomerization of D-tyrosine to L-tyrosine was also catalyzed by intact cells.

Thus, L-tyrosine or L-dopa could be synthesized from DL-serine and phenol or pyrocatechol by intact cells of Erwinia herbicola containing tyrosine phenol lyase.
\end{abstract}

Tyrosine phenol lyase is an enzyme which catalyzes the stoichiometric conversion of L-tyrosine to pyruvic acid, ammonia and phenol, and requires pyridoxal phosphate as a cofactor. ${ }^{1 \sim 7}$ Apparently homogeneous preparations of the enzyme were prepared in our laboratory from cells of Escherichia intermedia and Erwinia herbicola grown in media supplemented with L-tyrosine..$^{5,6,8\}} \mathrm{We}$ reported that the crystalline preparation of the enzyme catalyzes a series of $\alpha, \beta$-elimination $(1,2), \beta$-replacement $(3,4,5)$ and racemization (6) reactions..$^{9 \sim 11}$ )

\footnotetext{
t Microbiological Synthesis of L-Tyrosine and 3,4Dihydroxyphenyl-I-alanine. Part II.
}

$$
\begin{aligned}
& \text { L-Tyrosine }+\mathrm{H}_{3} \mathrm{O}-\text { pyruvate }+\mathrm{NH}_{3}+ \\
& \text { phenol } \\
& \text { L-Serine_-pyruvate }+\mathrm{NH}_{3} \\
& \text { L-Tyrosine }+ \text { pyrocatechol_L-dopa }+ \\
& \text { phenol } \\
& \text { L-Serine }+ \text { phenol_- L-tyrosine }+\mathrm{H}_{2} \mathrm{O} \\
& \text { L-Serine }+ \text { pyrocatechol_L-dopa }+ \\
& \mathrm{H}_{2} \mathrm{O} \\
& \text { L(D)-Alanine-DL-alanine }
\end{aligned}
$$

In the present paper, these reactions are studied with intact cells of Erwinia herbicola ATCC 21434 containing tyrosine phenol lyase. Synthesis of L-tyrosine or L-dopa from $\mathrm{D}$-serine and phenol or pyrocatechol are also described. 


\section{EXPERIMENTAL}

Chenicals. All chemicals used were commercial products. L-Dopa was purchased from Daiichi Kagaku Company, Ltd., Tokyo.

Microorganism. Erwinia herbicola ATCC 21434 was used as the enzyme source.

Preparation of intact cells. Intact cells containing tyrosine phenol lyase were prepared as previously described. ${ }^{12}$

Replacement reaction. The replacement reaction between $\mathrm{L}$-serine and phenol derivatives was studied under the following conditions. A reaction mixture containing $100 \mathrm{mg}$ of phenol derivatives, $200 \mathrm{mg}$ of L-serine, $50 \mathrm{mg}$ of ammonium chloride, $20 \mathrm{mg}$ of sodium sulfite, $10 \mathrm{mg}$ of EDTA and approximately $100 \mathrm{mg}$ of intact cells as wet base in a total volume of $10 \mathrm{ml}$ (pH 8.0 by ammonia) was incubated at $30^{\circ} \mathrm{C}$ for $4 \mathrm{hr}$. The replacement reaction between various amino acids, other than L-serine, and phenol or pyrocatechol, was carried out with various amino acids, instead of L-serine, and with phenol or pyrocatechol.

Elimination reaction. The elimination reaction of various amino acids was carried out as follows. An assay mixture containing $1 \mathrm{mg}$ or $10 \mathrm{mg}$ of amino acid, $50 \mathrm{mg}$ of ammonium chloride, $20 \mathrm{mg}$ of sodium sulfite, $10 \mathrm{mg}$ of EDTA and approximately $100 \mathrm{mg}$ of intact cells as wet base in a total volume of $10 \mathrm{ml}(\mathrm{pH} 8.0$ by ammonia) was incubated at $30^{\circ} \mathrm{C}$ for $4 \mathrm{hr}$.

Isomerization reaction. The isomerization reaction was investigated by determining the amounts of L-tyrosine formed from $D$-tyrosine. The rate of isomerization is expressed as the ratio of L-tyrosine to initial amount of D-tyrosine. A reaction mixture containing $100 \mathrm{mg}$ of D-tyrosine, $50 \mathrm{mg}$ of ammonium acetate, $20 \mathrm{mg}$ of sodium sulfite, $10 \mathrm{mg}$ of EDTA and approximately $100 \mathrm{mg}$ of intact cells as wet base in a total volume of $10 \mathrm{ml}$ ( $\mathrm{pH} 8.0$ by ammonia) was incubated at $30^{\circ} \mathrm{C}$ for $4 \mathrm{hr}$.

Analytical methods. (1) Qualitative analysis of the amino acids synthesized by the replacement reaction was made by paper chromatography using a solvent system of butanol-acetic acid-water $(4: 1: 2)$. These amino acids were detected by the ninhydrin reaction.

(2) Determinations of L-tyrosine and L-dopa were carried out as previously described. ${ }^{12}$

(3) Determination of pyruvic acid was carried out according to the method of Friedemann and Haugen. ${ }^{13}$ The assay solution was diluted to contain $0.02 \sim 0.1 \mathrm{~g}$ $\mathrm{d} l$ of pyruvic acid. Two milliters of this diluted assay solution and $2 \mathrm{ml}$ of $0.25 \% 2,4$-dinitrophenylhydrazine$2 \mathrm{~N} \mathrm{HCl}$ solution were mixed by stirring them in a test tube. Then the mixture was incubated at $30^{\circ} \mathrm{C}$ for $5 \mathrm{~min}$. The absorbancy at $517 \mathrm{~m} \mu$ of $4 \mathrm{ml}$ of sodium carbonate solution was determined after adding $2 \mathrm{ml}$ of $4 \mathrm{~N}$ sodium hydroxide solution. Pyruvic acid was determined from calibration of the standard curve prepared by the same procedure.

\section{RESULTS}

\section{Specificity of replacement reaction for phenol derivatives}

Specificity of the replacement reaction for phenol derivatives was studied with intact cells of Erwinia herbicola ATCC 21434. The replacement reaction was carried out in the presence of various phenol derivartives and L-serine in the reaction mixtures as described in experimental procedures, then the amino acids synthesized were detected with paper chromatography, L-Tyrosine and L-dopa were identified by comparing these $R f$ values with that of authentic samples. 2,4-L-Dopa synthesized from resorcinol and L-serine was identified by the method of Ueno et al. ${ }^{10}$ Aromatic amino acid from pyrogallol was detected only with ninhydrin, as authentic sample could not be obtained.

Paper chromatograms of the incubated mixtures are shown in Fig. 1. As shown in Table I, phenol, pyrocatechol, resorcinol and pyrogallol were changed to the amino acids corresponding to these phenol derivatives. L-Dopa was also synthesized from diacetyl catechol, as diacetyl catechol was changed to pyrocatechol by non-enzymatic hydrolysis during the reaction.

\section{Specificity of elimination reaction for various amino acids}

The relative rates of pyruvate formation from various amino acids by the elimination 


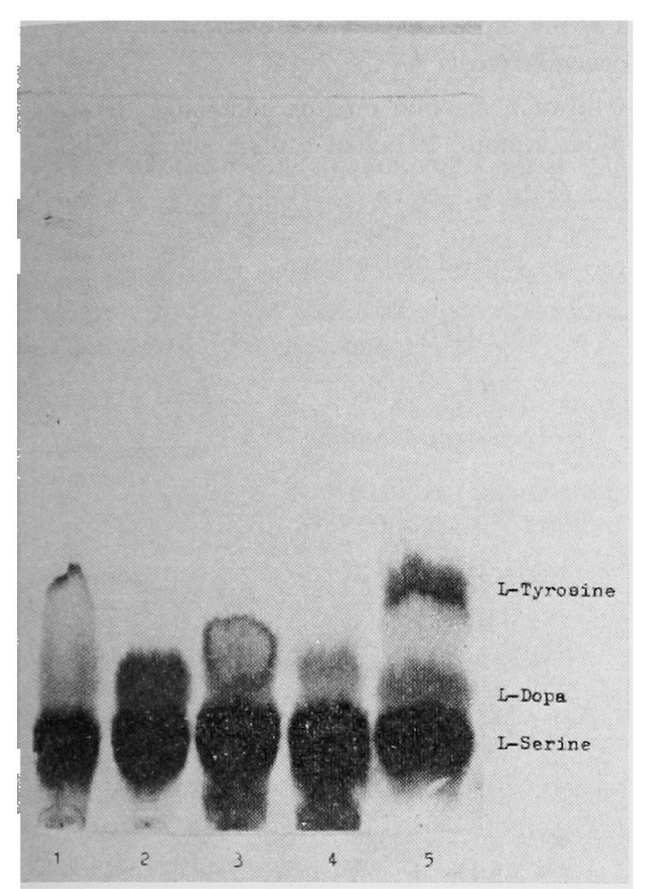

FIG. 1. Paper Chromatograms of Reaction Mixtures.

Solvent; $n$-butanol: acetic acid: water $(4: 1: 2)$. Phenol derivatives in the reaction mixture as substrate; 1) phenol, 2) pyrocatechol, 3) resorcinol, 4) pyrogallol and 5) the standard mixture containing $0.5 \%$ L-Tyr, $0.5 \%$ L-Dopa and $0.5 \%$ L-Ser.

reaction were investigated with intact cells of Erwinia herbicola ATCC 21434. Table II shows that pyruvate was formed from L(D)tyrosine, L(D)-dopa, L(D)-serine, L-cysteine, L-cystine or $S$-methyl-L-cysteine, as shown previously with crystalline enzyme preparation. ${ }^{8)}$ Seventy six percents of L-tyrosine was degraded to pyruvate in a reaction mixture containing lower concentration $(10 \mathrm{mg} / \mathrm{dl})$ of L-tyrosine, but only $8 \%$ was degraded to pyruvate when higher concentration $(100 \mathrm{mg} /$ dl) of L-tyrosine was added to the reaction mixture. This tendency was observed in the reaction mixtures containing L(D)-tyrosine, L(D)-dopa, L-cysteine, L-cystine and $S$-methyl$\mathrm{L}$-cysteine, but not $\mathrm{L}$-serine and $\mathrm{D}$-serine. Pyruvate formation from D-amino acids also proceeded with intact cells, but, at lower rates in comparison with those from L-amino acids. D-Serine, however, showed higher reactivity than other D-amino acids when $100 \mathrm{mg}$ of D-serine was used as substrate. $\alpha$-Keto-butyrate was formed from L-threonine, instead of pyruvate, by the intact cells.

\section{Specificity of replacement reaction for various amino acids}

The replacement reaction between various amino acids and phenol or pyrocatechol was studied using intact cells of Erwinia herbicola ATCC 21434. The synthesis of L-tyrosine or L-dopa from various amino acids and phenol or pyrocatechol were qualitatively determined by paper chromatography, as shown in Table III. The replacement reaction was observed with L(D)-tyrosine, L(D)-dopa, L(D)-serine, Lcysteine, L-cystine and $S$-methyl-L-cysteine. In addition, a small amount of L-tyrosine or L-dopa was synthesized with L-alanine and D-alanine. Of the various amino acids used L-serine and D-serine were the most efficient substrates for the synthesis of L-tyrosine or L-dopa. L(D)-Tyrosine and L(D)-dopa were not useful substrates, since the liberated phenol or pyrocatechol inhibited the replacement reaction. These results show that DL-serine may be available as substrate for the preparation of L-tyrosine or L-dopa.

\section{Identification of L-tyrosine and L-dopa} synthesized from D-serine

D-Serine was shown to be useful as substrate for the preparation of L-tyrosine or L-dopa (Table IV). Isolation of the tyrosine or dopa synthesized from D-serine was carried out by the procedure described previously ${ }^{12}$, using the reaction mixtures shown in Table I. The crystalline products isolated were subjected to paper chromatography and elemental analysis. Optical activity was determined with a polarimeter and the result obtained 
Table I. Formation of Aromatic Amino Acids from l-Serine and Phenol. Derivatives By INTACT Cells of Erwinia herbicola ATCC 21434

The reaction was carried out at $30^{\circ} \mathrm{C}$ for $4 \mathrm{hr}$ in $10 \mathrm{ml}$ of a reaction mixture containing $100 \mathrm{mg}$ of phenol derivatives, $200 \mathrm{mg}$ of L-serine, $50 \mathrm{mg}$ of ammonium acetate, $20 \mathrm{mg}$ of sodium sulfite, $10 \mathrm{mg}$ of EDTA and $100 \mathrm{mg}$ of intact cells (pH 8.0 by ammonia).

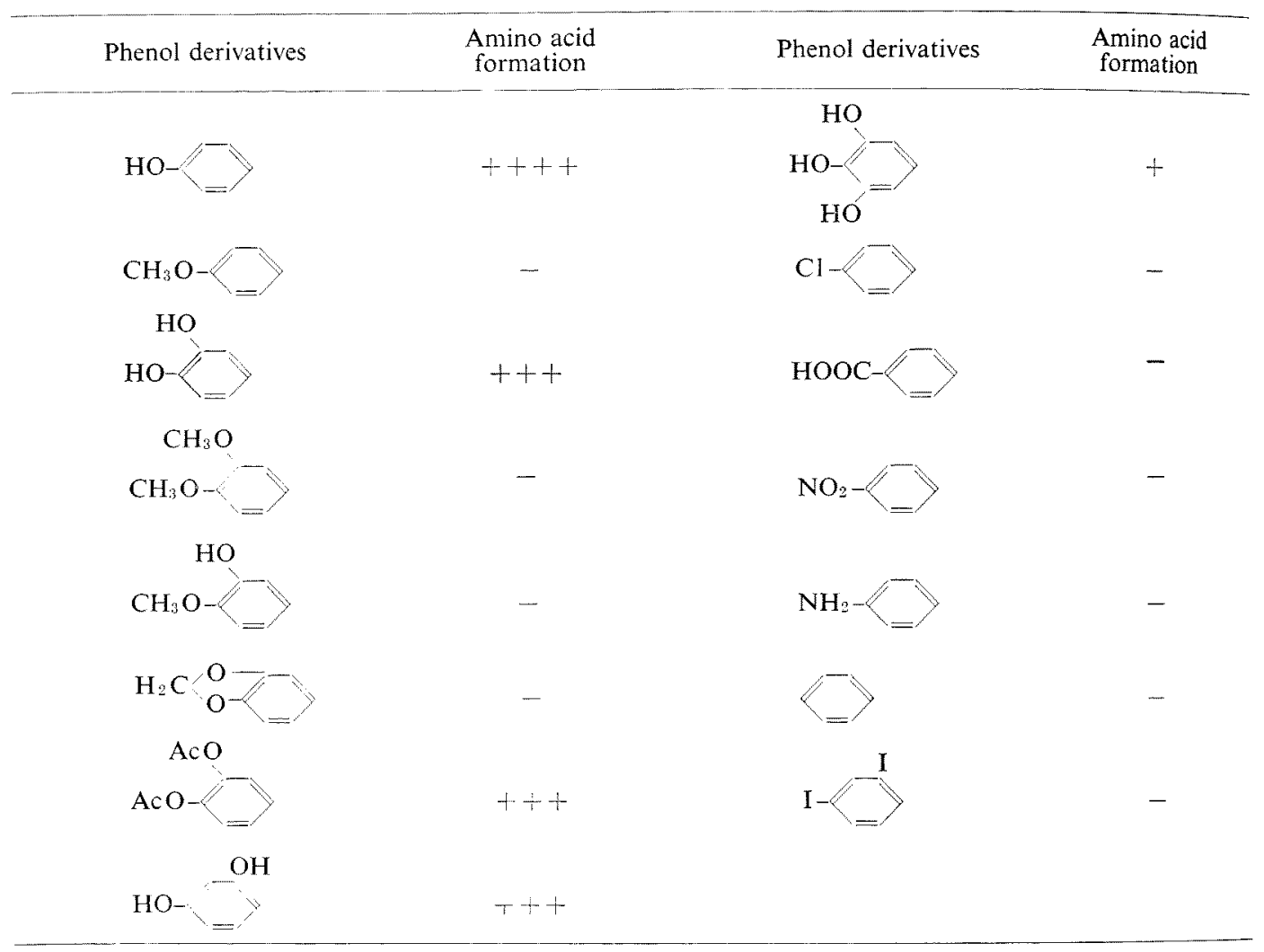

was further confirmed by microbiological analysis. Table IV shows the recovery of tyrosine during isolation from the reaction mixtures, in which the recovery of tyrosine synthesized from phenol and $\mathrm{L}$ or D-serine, was about $64 \%$ in each. Also, the recovery of L-dopa synthesized from pyrocatechol and $\mathrm{L}$ or D-serine was about $55 \sim 56 \%$ from each. The isolated crystals of tyrosine gave a single spot on the paper chromatogram with a bluishpurple color after the ninhydrin reaction and gave an $R f$ value identical with authentic L-tyrosine. Very close agreement between observed and calculated values was in elemental analysis shown in Tables V and VI. Moreover, the optical activity of the product was identical with that of authentic L-tyrosine, $[\alpha]_{D}^{25}=-11.9(c=5,1 \mathrm{~N} \mathrm{HCl})$. The isolated crystals of dopa was identified in similar way as that of tyrosine and gave results identical with authentic L-dopa. The optical activity of the isolated dopa was the same as authentic L-dopa, $[\alpha]_{\mathrm{D}}^{25}=-11.8 \quad(c=3.7,4 \% \quad \mathrm{HCl})$ These results indicate that the amino acids synthesized from $D$-serine by this enzymatic method were entirely of the L-form.

5. Isomerization reaction from D-tyrosine th 


\section{TABle II. Elimination Reactions of VARIOUS AMINo Acios}

The reaction was carried out at $30^{\circ} \mathrm{C}$ for $4 \mathrm{hr}$ in $10 \mathrm{ml}$ of a reaction mixture containing $1 \mathrm{mg}$ or $10 \mathrm{mg}$ of amino acid as substrate, $50 \mathrm{mg}$ of ammonium chloride, $20 \mathrm{mg}$ of sodium sulfite, $10 \mathrm{mg}$ of EDTA and $100 \mathrm{mg}$ of intact cells in a total volume of $10 \mathrm{ml}$ $(\mathrm{pH} \mathrm{8.0)}$. Pyruvic acid was determined according to the method of Friedemann and Haugen. ${ }^{13}$

\begin{tabular}{|c|c|c|}
\hline \multirow{2}{*}{$\begin{array}{l}\text { Amino acid as } \\
\text { substrate }\end{array}$} & \multicolumn{2}{|c|}{$\begin{array}{l}\text { Pyruvate formation } a)(\%) \text { by } \\
\text { elimination reaction }\end{array}$} \\
\hline & $\begin{array}{l}\text { Concentration } \\
10 \mathrm{mg} / \mathrm{dl}\end{array}$ & $\begin{array}{l}\text { of substrate } \\
100 \mathrm{mg} / \mathrm{dl}\end{array}$ \\
\hline L-Tyrosine & 76 & 8 \\
\hline D-Tyrosine & 32 & 6 \\
\hline L-Dopa & 35 & 20 \\
\hline D-Dopa & 18 & 7 \\
\hline L-Serine & 48 & 57 \\
\hline D-Serine & 29 & 36 \\
\hline L-Cysteine & 36 & 12 \\
\hline L-Cystine & 24 & 16 \\
\hline S-Methyl-L-cysteine & 25 & 16 \\
\hline L-Threonine & 0 & 0 \\
\hline L-Tryptophan & 0 & 2 \\
\hline L-Alanine & 0 & 1 \\
\hline D-Alanine & 0 & 1 \\
\hline L-Homoserine & 0 & 0 \\
\hline L-Histidine & 0 & 0 \\
\hline L-Phenylalanine & 0 & 0 \\
\hline L-Methionine & 0 & 0 \\
\hline
\end{tabular}

a) The relative rates of pyruvate formed from amino acids. (100 $\mu$ mole of pyruvate formed per $\mu$ mole of amino acid.)

\section{L-tyrosine}

As described above, we confirmed that pyruvate formation from higher concentration of L-tyrosine or D-tyrosine as substrate, by the elimination reaction, proceeded at rather low rates, and that only L-form of tyrosine was formed from D-serine and phenol. Then, we assumed that isomerization from D-tyrosine to L-tyrosine might be catalyzed by intact cells of Erwinia herbicola ATCC 21434 containing tyrosine phenol lyase.

The isomerization reaction from $\mathrm{D}$-tyrosine to L-tyrosine was carried out as described in "experimental procedures." The amounts of

\section{Table III. Replacement Reactions of VARIOUS AMINo ACIDS}

The reaction was carried out at $30^{\circ} \mathrm{C}$ for $4 \mathrm{hr}$ in $10 \mathrm{ml}$ of a reaction mixture containing $100 \mathrm{mg}$ of phenol or pyrocatechol, $200 \mathrm{mg}$ of various amino acids, $50 \mathrm{mg}$ of ammonium chloride, $20 \mathrm{mg}$ of sodium sulfite, $10 \mathrm{mg}$ of EDTA and $100 \mathrm{mg}$ of intact cells (pH 8.0 by ammonia).

\begin{tabular}{|c|c|c|}
\hline $\begin{array}{l}\text { Amino acid as } \\
\text { substrate }\end{array}$ & $\begin{array}{l}\text { L-Tyrosine } \\
\text { formation }\end{array}$ & $\begin{array}{c}\text { L-Dopa } \\
\text { formation }\end{array}$ \\
\hline L-Tyrosine & & ++ \\
\hline D-Tyrosine & & + \\
\hline L-Dopa & +-+ & \\
\hline D-Dopa & + & \\
\hline L-Serine & $++t+$ & $+1++$ \\
\hline D-Serine & $+\frac{1}{1}+$ & ++ \\
\hline L-Cysteine & +++ & + \\
\hline L-Cystine & $+\ldots$ & + \\
\hline S-Methyl-L-cysteine & $+\ldots$ & + \\
\hline L-Threonine & - & - \\
\hline L-Tryptophan & - & - \\
\hline L-Alanine & \pm & \pm \\
\hline D-Alanine & + & \pm \\
\hline L...-Homoserine & - & $=$ \\
\hline L-Histidine & - & - \\
\hline L-Phenylalanine & - & - \\
\hline L-Methionine & - & - \\
\hline
\end{tabular}

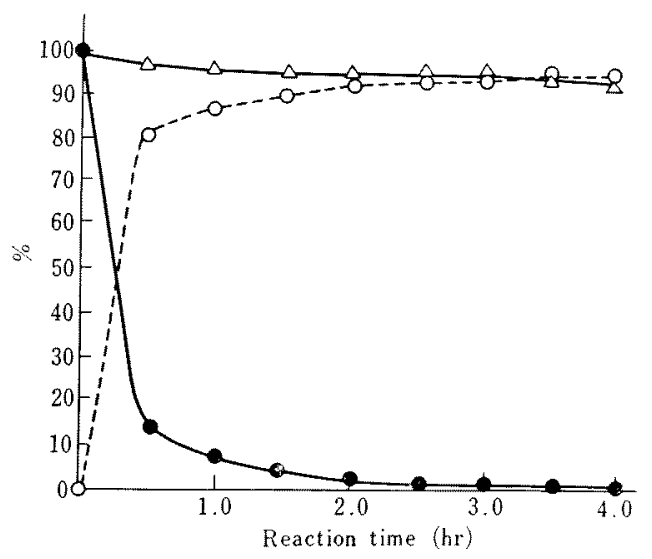

FIG. 2. Isomerization of D-Tyrosine to L-Tyrosine by Intact Cells of Erwinia herbicola ATCC 21434 Containing Tyrosine Phenol Lyase.

The reaction was carried out at $37^{\circ} \mathrm{C}$ for $4 \mathrm{hr}$ in $10 \mathrm{ml}$ of a reaction mixture containing $100 \mathrm{mg}$ of $\mathrm{L}$ or D-tyrosine, $50 \mathrm{mg}$ of ammonium acetate, $20 \mathrm{mg}$ of sodium sulfite, $10 \mathrm{mg}$ of EDTA and approximately $100 \mathrm{mg}$ of wet cells ( $\mathrm{pH} 8.0$ by ammonia).

$\triangle-\triangle \mathrm{L}$-Tyrosine as substrate. $\mathrm{O}-\mathrm{O} \mathrm{L}$-Tyrosine formed from D-tyrosine, - D-Tyrosine as substrate. 
Table IV. L-Tyrosine AND L-Dopa Synthesis From D-SERINe

\begin{tabular}{|c|c|c|c|}
\hline Substrate & Product & $\begin{array}{l}\text { Amounts of } \\
\text { product } \\
(\mathrm{g} / \mathrm{dl})\end{array}$ & $\begin{array}{l}\text { Recovery of product } \\
\text { from reaction } \\
\text { mixture }(\%)\end{array}$ \\
\hline Phenol & L-Serine L-Tyrosine & $1.22^{a)}(1.18)^{b)}$ & 64.7 \\
\hline Phenol & D-Serine $\mathrm{L}$-Tyrosine & $1.05 \quad(1.05)$ & 64.3 \\
\hline Pyrocatechol & L-Serine L-Dopa & 0.68 & 55.3 \\
\hline Pyrocatechol & D-Serine L-Dopa & 0.60 & 56.8 \\
\hline
\end{tabular}

Table V. Properties of l-Tyrosine Crystals

\begin{tabular}{|c|c|c|c|c|}
\hline \multirow[t]{2}{*}{ Substrate } & \multirow{2}{*}{$\begin{array}{c}\text { Optical } \\
\text { activity } \\
{[\alpha]_{D}^{25}}\end{array}$} & \multicolumn{3}{|c|}{$\begin{array}{l}\text { Elemental } \\
\text { analysis }^{b /}\end{array}$} \\
\hline & & $\mathrm{C}$ & $\mathrm{H}$ & $\mathrm{N}$ \\
\hline Phenol L-serine & -11.9 & 59.67 & 6.10 & 7.73 \\
\hline Phenol D-serine & -12.0 & 59.65 & 6.11 & 7.72 \\
\hline Authentic L-tyrosine & -11.9 & 59.67 & 6.11 & 7.72 \\
\hline
\end{tabular}

a) $(c=5,1 \times \mathrm{HCl})$ b) Calculated: C, $59.66, \mathrm{H}, 6.12, \mathrm{~N}, 7.73$.

Table VI. Properties of l-Dopa Crystals

\begin{tabular}{|c|c|c|c|c|}
\hline \multirow[t]{2}{*}{ Substrate } & $\begin{array}{c}\text { Optical } \\
\text { activity }^{a}\end{array}$ & & $\begin{array}{l}\text { Elemental } \\
\text { analysis }{ }^{b}\end{array}$ & \\
\hline & {$[\alpha]_{\mathrm{D}}^{85}$} & $\mathrm{C}$ & $\mathrm{H}$ & $N$ \\
\hline Pyrocatechol L-serine & -11.8 & 54.91 & 5.77 & 6.92 \\
\hline Pyrocatechol D-serine & -11.8 & 54.84 & 5.68 & 6.98 \\
\hline Authentic L-dopa & -11.8 & 54.86 & 5.70 & 6.95 \\
\hline
\end{tabular}

a) $(c=3.7,4 \% \mathrm{HCl})$ b) Calculated: C, $54.82, \mathrm{H}, 5.62, \mathrm{~N}, 7.10$.

total tyrosine and of L-tyrosine were determined every $30 \mathrm{~min}$. Total tyrosine was determined by the colorimetry and L-tyrosine by microbioassay. The residual D-tyrosine was calculated by subtracting L-tyrosine from total tyrosine.

Figure 2 shows that approximately $80 \%$ of D-tyrosine was isomerized in $30 \mathrm{~min}$, and that about $92 \sim 95 \%$ of the D-tyrosine was changed to L-tyrosine, and $3 \sim 4 \%$ of the $\mathrm{D}$ tyrosine was phenol and pyruvate during 3 hr incubation. No conversion of L-tyrosine to D-tyrosine, however, was observed. LTyrosine was slightly degraded to phenol and pyruvate, but almost all remained intact under the conditions used. Thus, the isomerization reaction from $\mathrm{D}$-tyrosine to L-tyrosine was proved to be catalyzed by intact cells containing tyrosine phenol, lyase.

\section{DISCUSSION}

Various reactions catalyzed by intact cells of Erwinia herbicola ATCC 21434 containing tyrosine phenol lyase were studied in this paper. The results are as follows. Phenol, pyrocatechol, resorcinol and pyrogallol could be used as substrate to form the corresponding 


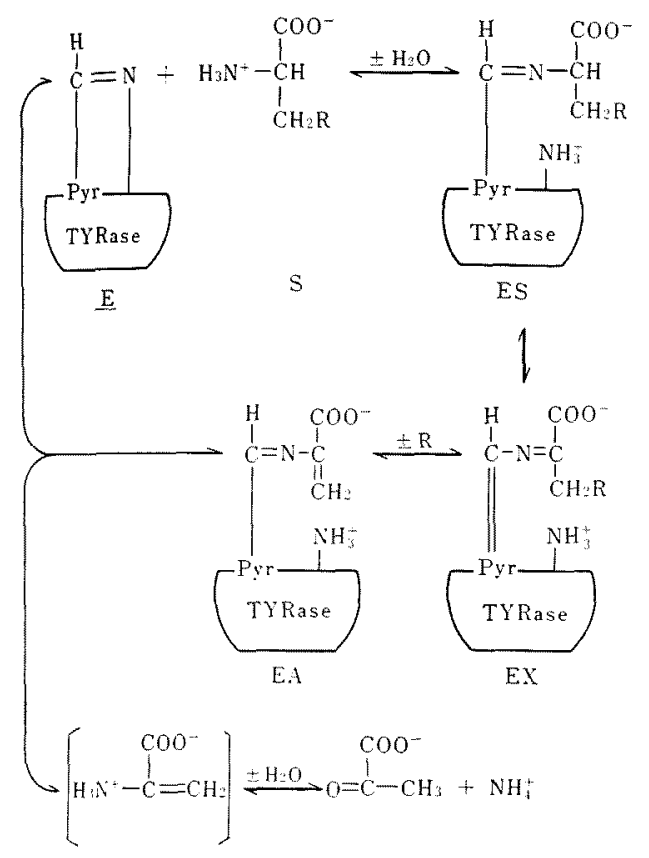

Fig. 3. Schematic Representation of the Mechanism Discussed in the Text for Reactions Catalyzed by Tyrosine Phenol Lyase.

E, S, ES, EX and EA represent enzyme, substrate, aldimine, ketimine and enzyme- $\alpha$-aminoacrylate intermediates, respectively.

aromatic amino acids via the replacement reaction. L(D)-Tyrosine, L(D)-dopa, L(D)serine, L-cysteine, L-cystine and $S$-methyl-Lcysteine were degraded to pyruvate and ammonia, via the elimination reaction, by intact cells, and D-amino acid could be used as substrate under these conditions. Of the amino acids tested, L-serine and D-serine were the most useful substrates for the preparation of L-tyrosine or L-dopa. The L-tyrosine or L-dopa synthesized from D-serine and phenol or pyrocatechol was confirmed to be entirely of the L-form. Then, DL-serine was the most useful substrate for the preparation of Ltyrosine or L-dopa in this enzymatic reaction. The isomerization reaction from $\mathrm{D}$-tyrosine to l-tyrosine was found in the present work by intact cells containing tyrosine phenol lyase.

Yamada et al. ${ }^{5 \sim 11}$ interpreted the reaction mechanism catalyzed by tyrosine phenol lyase, as shown in Fig. 3, by adapting the general mechanisms for the pyridoxal-phosphate dependent reaction proposed by Braunstein and Shemyakin ${ }^{14}$ and by Metzler, Ikawa and Snell. ${ }^{15}$

Using crystalline preparations of tyrosine phenol lyase, Yamada et $a l^{\text {s) }}$ posturated the mechanism of tyrosine phenol lyase catalyzed reaction, as shown in Fig. 3. In catalysis of $\alpha, \beta$-elimination reactions, the amino acid, $\mathrm{S}$ (R-phenolyl radical, $-\mathrm{SCH}_{3},-\mathrm{OH}$ or $-\mathrm{SH}$ ), interacts with the enzyme, $\mathrm{E}$, to form reversibly, by eliminating $\mathrm{H}^{+}$and $\mathrm{R}^{-}$(phenol, $\mathrm{CH}_{3} \mathrm{SH}$, $\mathrm{H}_{2} \mathrm{O}$ or $\mathrm{H}_{2} \mathrm{~S}$ ), aldimine, ES, Ketimine, EX, and enzyme- $\alpha$-amino acrylate, EA, intermediates. The enzyme- $\alpha$-amino acrylate intermediate, EA, hydrolyzes to yield pyruvate and ammonia and regenerate the enzyme, E. In the presence of phenol or pyrocatechol, addition to $\mathrm{EA}$, rather than hydrolysis, can occur to yield L-tyrosine or L-dopa by reversal of these reactions. In the present investigation, these elimination and replacement reactions were studied with the intact cells of Erwinia herbicola ATCC 21434 containing high tyrosine phenol lyase activity. Phenol, pyrocatechol, resorcinol and pyrogallol could be used as substrates for the replacement reaction to form the corresponding aromatic amino acids. L(D)-Tyrosine, L(D)-dopa, L(D)-serine, Lcysteine, L-cystine and $S$-methyl-L-cysteine were used as substrate for the elimination and replacement reactions by the intact cells. Of these amino acids, L(D)-serine was shown to be the most useful for the preparation of $L$ tyrosine or L-dopa.

D-Form of these amino acids could be used as substrate for these reactions by the intact cells. The L-tyrosine or L-dopa synthesized from D-serine and phenol or pyrocatechol was isolated from a large scale reaction mixture 
and identified to be entirely of the L-form. With the crystalline enzyme preparation from Escherichia intermedia, Kumagai et al. ${ }^{11}$ reported that this enzyme catalyzed the racemization reaction of $\mathrm{L}(\mathrm{D})$-alanine. They interpreted the mechanism of the racemization reaction as that it proceeds by the temparary abolition of the center of asymmetry at the $\alpha$-carbon atom of alanine, attending reversible rearrangement of the aldimine intermediate to the ketimine one (see Fig. 3). Then, it seems likely that, under the conditions of the present investigation, D-form of the amino acid substrate may be racemized to DL-form, then that $\mathrm{L}$-form formed undergoes the replacement reaction with phenol or pyrocatechol to Ltyrosine and L-dopa.

In the present investigation, D-tyrosine was isomerized to L-tyrosine by the intact cells containing tyrosine phenol lyase. Details of the mechanism of this isomerization reaction is unknown, but currently under investigation, with crystalline enzyme preparations, in our laboratory.

Acknowledgment. We wish to thank Prof. $\mathbf{K}$. Ogata, Kyoto University, Kyoto, and Mr. K. Akino, Dr. T. Tsunoda and Dr. M. Takahashi, of the Central Research Laboratories, Ajinomoto Co., Inc., Kawasaki, for their interest and advice during the course of this work.

\section{REFERENCES}

1) Y. Kakihara and K. Ichihara, Med. J. Osaka Univ. (Osaka), 3, 497 (1953).

2) M. Uchida, Y. Taketomo, Y. Kakihara and K. Ichihara, ibid., 3, 509 (1953).

3) H. Yoshimatsu, ibid, 9, 727 (1957).

4) N. Brot, Z. Smit and H. Weissbach, Arch. Biochem. Biophys., 112, 1 (1965).

5) H. Yamada, H. Kumagai, H. Matsui, H. Ohgishi and K. Ogata, Biochem. Biophys. Res. Commun., 33, 10 (1968).

6) H. Kumagai, H. Yamada, H. Matsui, H. Ohgishi and K. Ogata, J. Biol. Chem., 245, 1767 (1970).

7) H. Kumagai, H. Yamada, H. Matsui, H. Ohgishi and K. Ogata, ibid., 245, 1773 (1970).

8) H. Kumagai, N. Kashima, H. Torii, H. Yamada, H. Enei and S. Okumura, Agr. Biol. Chem., in press.

9) H. Kumagai, H. Matsui, H. Ohgishi, K. Ogata, H. Yamada, T. Ueno and H. Fukami, Biochim. Biophys. Res. Commun., 34, 266 (1969).

10) T. Ueno, H. Fukami, H. Ohgishi, H. Kumagai and H. Yamada, Biochim. Biophys, Acta, 206, 476 (1970).

11) H. Kumagai, N. Kashima and H. Yamada, Biochem. Biophys. Res. Commun., 39, 796 (1970).

12) H. Enei, H. Matsui, K. Yamashita, S. Okumura and H. Yamada, Agr. Biol. Chem., 36, 1861 (1972).

13) T. E. Friedemann and G. E. Haugen, J. Biol. Chem., 147, 415 (1943).

14) A. E. Braunstein and M. M. Shemyakin, Biokhimiya, 18, 393 (1953).

15) D. E. Metzler, M. Ikawa and E. E. Snell, J. Am. Chem. Soc., 76, 648 (1954). 